\title{
THE EFFECT OF INFORMATION AND COMMUNICATION TECHNOLOGY (ICT) ON INDONESIAN BILATERAL TRADE WITH ASEAN COUNTRIES
}

\author{
Pengaruh Teknologi Informasi dan Komunikasi (TIK) pada Perdagangan \\ Bilateral Indonesia dengan Negara-negara ASEAN
}

\author{
${ }^{1}$ Dyah Titis Kusuma Wardani, ${ }^{2}$ Muhammad Azizurrohman, ${ }^{1}$ Aliza Hari Tanthowy \\ ${ }^{1}$ Faculty of Economics and Business, Universitas Muhammadiyah Yogyakarta, Kampus Terpadu \\ UMY, JI Brawijaya, Kasihan, Bantul, Yogyakarta 55183, Indonesia \\ ${ }^{2}$ National Chiayi University, No.300 Syuefu Rd., Chiayi City 60004, Taiwan (R.O.C.) \\ E-mail: dyah.wardani@umy.ac.id
}

Naskah diterima: 28/09/2018; Naskah direvisi: 06/07/2019; Disetujui diterbitkan: 21/11/2019

Dipublikasikan online: 31/12/2019

\begin{abstract}
Abstrak
Teknologi Informasi dan Komunikasi (TIK) dan perdagangan memiliki keterkaitan untuk mendukung pencapaian efisiensi pasar melalui pengurangan biaya, peningkatan promosi dan penciptaan kerangka distribusi. Penelitian ini bertujuan untuk menganalisis dampak pengembangan TIK pada perdagangan bilateral antara Indonesia dan mitra dagangnya di negara-negara ASEAN. Penelitian ini menggunakan kerangka Model Gravitasi dengan data panel periode 2010-2017, dengan estimasi model random effect. Sampel yang digunakan adalah sembilan negara anggota ASEAN yang merupakan mitra dagang Indonesia. Hasil kajian menunjukkan bahwa, TIK memiliki dampak yang positif dan signifikan terhadap volume ekspor Indonesia ke negara-negara ASEAN. Variabel lain seperti PDB riil Indonesia and mitra dagang ASEAN serta populasi mitra dagang juga berpengaruh positif dan signifikan. Sementara jarak dan nilai tukar riil memiliki pengaruh negatif dan signifikan terhadap ekspor Indonesia ke ASEAN. Berdasarkan hasil penelitian ini, beberapa implikasi kebijakan antara lain, Indonesia dapat mengembangkan kemitraan perdagangan strategis dengan negaranegara yang memiliki ukuran ekonomi besar dan telah mencapai pengembangan TIK yang tinggi seperti Singapura dan Malaysia, sehingga dapat meningkatkan volume perdagangan ke ASEAN terutama untuk produk-produk berbasis TIK.
\end{abstract}

Kata Kunci: Teknologi Informasi dan Komunikasi; Perdagangan Bilateral; Indeks Pengembangan TIK (IPTIK); Model Gravitasi

\begin{abstract}
Information and Communication Technology (ICT) and trade have a relationship to support the achievement of market efficiency through cost reduction, increase promotion and distribution framework creation. This study aims to analyze the impacts of ICT Development on bilateral trade between Indonesia and its trading partners in the ASEAN countries. Using an extended panel gravity model framework and panel data models for the period 2010-2017 employing a random effect model estimator. The sample includes nine ASEAN member countries as Indonesia's trading partners. Results indicate that ICT Development has positive and significant impacts on Indonesian export volume toward ASEAN countries. Other variables such as Indonesian RGDP, partners' RGDP and population have a positive and significant effect on Indonesia export to ASEAN. Meanwhile, distance and real exchange rates have a negative and significant effect on Indonesian export. Based on estimation results, some policy implications can be derived. For instance, Indonesia may develop strategic trading partnerships with countries that have a large economic size and have achieved high levels of ICT development such as Singapore and Malaysia, in order to increase Indonesian trade volume to ASEAN countries, especially on ICT based products.
\end{abstract}


Keywords: Information and Communication Technology; Bilateral Trade; ICT Development Index (IDI); Gravity Model

JEL Classification: O33; F10; C43; C29

\section{INTRODUCTION}

The development of electronicsbased Information and Communication Technology (ICT) has a connection to trade, which is to reduce fixed costs include the searching cost of the market, advertising, and establishing network distribution. Moreover, the use of ICT reduces delays in information transmission, therefore trade planning become more efficient and accurate. The linkage between ICT and trade particularly to achieve the efficiency of the market such as reducing cost, increasing promotion, and establishing a vast distribution network. This is enforced by Harris (1995), he argues that economists have long recognized the importance of communication costs in international trade since communication cost is an important determinant of trade costs. Discussion of the last quarter of the recent $20^{\text {th }}$ century often cites the technological progress of telecommunication might reduce communication costs as an important contributor to reduce trade costs (Fink et al., 2005). Furthermore, ASEAN member countries have identified eleven priority sectors such as agriculture-based products, rubberbased products, wood-based products, fisheries, textiles, air travel, automotive products, electronics, information or communication technology sector (ICT) by-products and services related to ecommerce, apparel, tourism and healthcare (Pangestu, 2010).

One of eleven priority sectors of ASEAN is information or Communication technology sector (products and services) related to ecommerce, therefore this research focused on ASEAN countries since based on Minister of Trade Republic Indonesia, ASEAN has agreed to accelerate regional integration on one of eleven priority sectors, such as communication technology sector (ICT) by-products and services by 2010 (Pangestu, 2010). Furthermore, ASEAN is committed to building a Community by 2015. To realize this goal, a community of enhanced connectivity is essential because a well-connected ASEAN, from its transportation networks to its peoples, will contribute towards a more competitive and resilient ASEAN as it 
will bring peoples, goods, services, and capital closer together under the ASEAN Charter (Master Plan on ASEAN Connectivity, 2010). This will ensure continued peace and prosperity for its peoples. This Master Plan on ASEAN Connectivity is a key step towards realizing this vision. Moreover, connectivity in ASEAN refers to the physical, institutional and people-topeople linkages that comprise the foundational support and facilitative means to achieve the economic, political-security and socio-cultural pillars towards realizing the vision of an integrated ASEAN Community. The physical linkages such as transport, ICT and energy (Master Plan on ASEAN Connectivity, 2010). In addition, to boost the intra-ASEAN trade, ASEAN improves regional economic integration through the formation of the ASEAN Economic Community (AEC). Consequently, in 2020 AEC should become a single market providing the free flow of five core such as the free movement of goods, services, investment, capital and skilled labor (ASEAN Economic Community Blueprint, 2008).

ASEAN signed a Framework Agreement for the Integration of Priority
Sectors in 2004. This assignation aims to accelerate integration between members. As in 2003, the priority sectors estimated for more than $50 \%$ of the intra-ASEAN trade. Furthermore, ASEAN which for a long time becomes a symbol of successful commitment in trade faces serious challenges, that is, technological change that may threaten the very model of labor-intensive industrialization (ASEAN Framework Agreement for the Integration of Priority Sectors, 2004). Moreover, there is also criticism against globalization that may reduce access to important markets.

A comprehensive analysis of the evolution of trade in East Asian and trade policies in goods and services leads to the conclusion that is, the extent to which ASEAN is able to manage the global challenge depends on how they able to tackle the three challenges at the national and regional level. The first is the one influential country in the East Asian region, such as China, as a giant in the world trade. China accounts for almost $14 \%$ of world exports and $10 \%$ of world imports that basically change the trade patterns and opportunities of its neighbors (Sally \& Sen, 2005). The second is, the enactment of asymmetric reforms at the national level, that is, 
extraordinary openness to trade in goods and investment along with relatively limited service policies that impact on the development of comparative advantage and the growth of productivity in each country. The third is, that the variance between relatively light and patchy agreements that control trade and investment in the region and the substantial of regional and global value chains are the main drivers to increase the growth of productivity. On the other hand, the rapid opening of China and its accession to the WTO have concentrated southeast-Asian minds. China's rise has led to fear that Southeast Asia will lose out, especially in the market for FDI. The emergence of India, though slower and less dramatic than that of China, has begun to exert a similar effect (Sally and Sen, 2005). Therefore, to resolve those challenges, ASEAN has to implement eleven priority sectors in the AEC single market.

Moreover, within ICT development, the global cost of communication particularly in trade activity tends to reduce. Decreasing global communication costs has facilitated an increase in global trade through cost reduction. The progression of information and communication technology in this research is captured in the information and Communication Development Index (IDI). There are some indicators for calculating ICT that are used in empirical studies. For example, infostate that has two components including infodensity and infouse is created by ORBICOM (Sciadas, 2003) and the International Telecommunication Union (ITU) (ITU 2010, 2011) calculates data on ICT development index (IDI). In order to evaluate the impact of ICT on trade flows between Indonesia and ASEAN trade partners, from 2010 to 2017 we consider ICT Development Index (IDI) consists of telecom services investment, percentage of internet users and international internet bandwidth (Hassani, et al. 2015). Our approach is the gravity equation. Gravity equations (Linder 1961; Linnemann 1966) relate trade flows to some factors about exporter and importer countries (Hassani et al., 2015). The hypothesis of this research said that IDI as a proxy of ICT development and it is expected to impact bilateral trade among ASEAN countries.

\section{METHODS}

This research employed the ICT Development Index (IDI). Recognizing 
that ICT is designed to be a global index and could become an engine of development, therefore, this concept of ICT is a key to the ICT Development Index's conceptual framework. The process of developing ICT, and the progression of a country to become an information society, can be captured using the hierarchy of ICT Development model is illustrated in Figure 1.

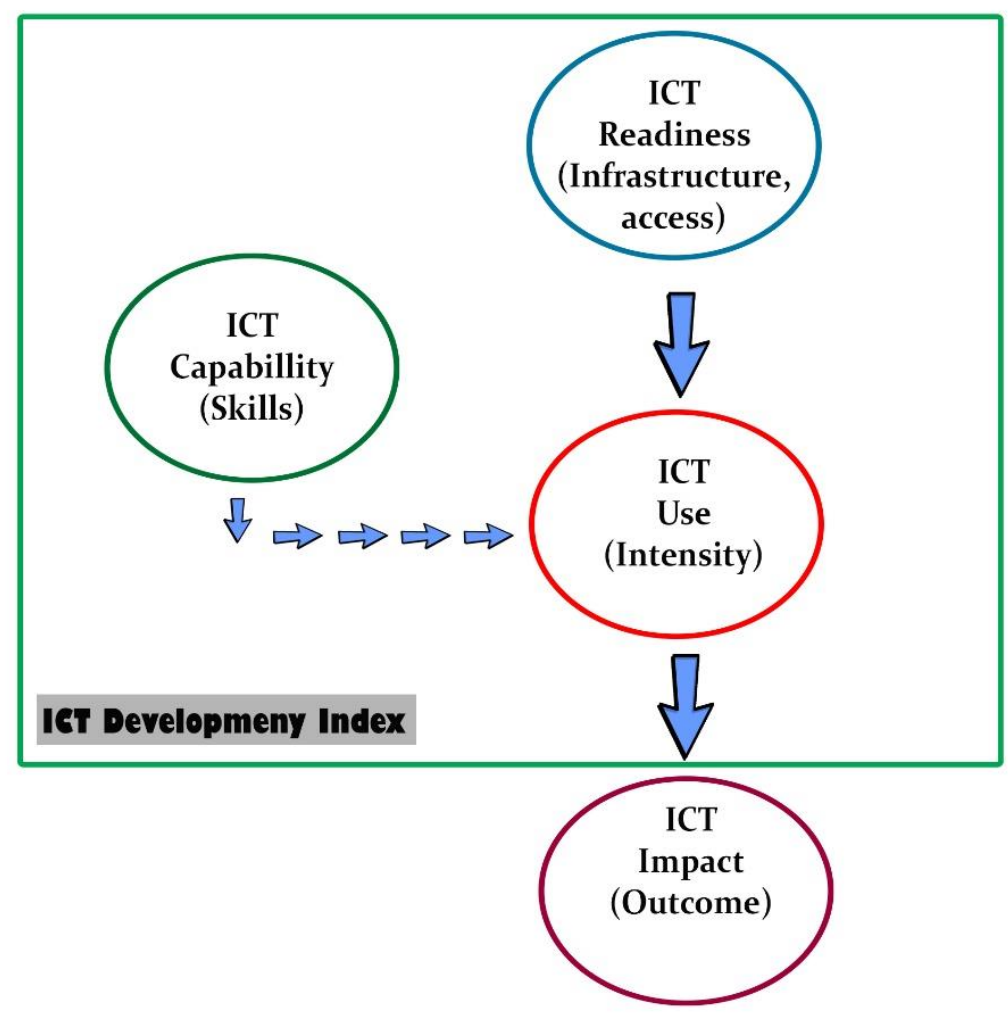

\section{Figure 1: Three Stages in the Evolution towards an Information Society}

Source: United Nations International Telecommunication Union (2009), modified Note:

Stage 1: ICT Readiness - denote the level of digital tools and physical infrastructure and access to ICTs.

Stage 2: ICT Intensity - denote the level of frequency in using ICTs in the society.

Stage 3: ICT Impact -denote the result or outcomes of more efficient and effective in ICT use.

According to this conceptual framework, the IDI is divided into three sub-indices, and a total of 11 indicators (Figure 2) is explained as follow:

- Access sub-index: This sub-index represents ICT readiness, and includes five infrastructure and access indicators, such as fixedtelephone subscriptions, mobilecellular telephone subscriptions, international Internet bandwidth per Internet user, households with a 
computer, and households with Internet access.

- Use sub-index: This sub-index denotes ICT intensity, and includes three indicators of intensity and use, for instance, level on how individuals using the Internet, how many fixed broadband subscriptions and mobilebroadband subscriptions.

- Skills sub-index: This sub-index indicates capabilities or skills which are important for ICT. It comprises three proxy indicators such as mean years of schooling, gross secondary enrolment, and gross tertiary enrolment. As these are proxy of indicators, rather than indicators directly measuring ICT-related skills, the skills sub-index is given less weight in the computation of the IDI than the other two sub-indices, that is, half of the other indices' weights.

Table 1: ICT Composition of ICT Development Index (IDI)

\begin{tabular}{lcrr}
\hline Variables & Number of Indicator & Weight in sub-Group & Weight of Sub-Group \\
\hline ICT Access & 5 & $100 \%$ & $40 \%$ \\
\hline ICT Use & 3 & $99 \%(100 \%)$ & $40 \%$ \\
\hline ICT Skills & 3 & $99 \%(100 \%)$ & $20 \%$ \\
\hline Total Weight: & & & $100 \%$ \\
\hline
\end{tabular}

Source: Modified from International Telecommunication Union (2009)

This research employed various techniques. First, we estimated the model using a pooled OLS. Then, we proceed with the Chow Test to determine which model is better between OLS and fixed effect. In addition, the Lagrange Multiplier test is also performed to compare which model is better between pooled OLS and random effect. After several tests performed, the random effect was chosen as the best model. In addition, the Breusch-Pagan test is employed for heteroscedasticity and finds out that the residual variance is constant over time. However, the autocorrelation test is not investigated here as cross-sectional dependence is not the main issue in micro panels with few years and a large number of individuals (Baltagi, 2008). In addition to testing the strength of the model (robustness check), this research is using one more estimation such as Poisson Pseudo Maximum Likelihood (PPML). Regression with PPML estimator support regression panel data estimation. 
Table 2: ICT Development Index: Indicators, References Values, and Weights

\begin{tabular}{|c|c|c|c|c|}
\hline Sub-indices & Indicators & Reference Value & $\%$ & Weights \\
\hline \multirow{5}{*}{ ICT Access } & 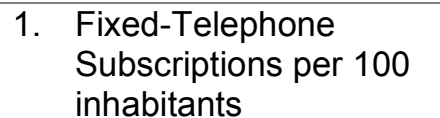 & 60 & 20 & \multirow{5}{*}{$40 \%$} \\
\hline & $\begin{array}{l}\text { 2. Mobile-cellular } \\
\text { telephone subscriptions } \\
\text { per } 100 \text { inhabitants }\end{array}$ & 120 & 20 & \\
\hline & $\begin{array}{l}\text { 3. International internet } \\
\text { bandwith(bit/s) per } \\
\text { internet users }\end{array}$ & 2'158'212 & 20 & \\
\hline & $\begin{array}{l}\text { 4. Percentage of } \\
\text { housholds with a } \\
\text { computer }\end{array}$ & 100 & 20 & \\
\hline & $\begin{array}{l}\text { 5. Percentage of } \\
\text { housholds with internet } \\
\text { access }\end{array}$ & 100 & 20 & \\
\hline \multirow{3}{*}{ ICT Use } & $\begin{array}{l}\text { 1. Percentage of } \\
\text { individuals using } \\
\text { internet }\end{array}$ & 100 & 33 & \multirow{3}{*}{$40 \%$} \\
\hline & $\begin{array}{ll}\text { 2. } & \text { Fixed-broadband } \\
\text { subscriptions per } 100 \\
\text { inhabitants }\end{array}$ & 60 & 33 & \\
\hline & $\begin{array}{l}\text { 3. Active mobile- } \\
\text { broadband } \\
\text { subscriptions per } 100 \\
\text { inhabitants }\end{array}$ & 100 & 33 & \\
\hline \multirow[b]{3}{*}{ ICT Skills } & 1. Mean years schooling & 15 & 33 & \multirow[b]{3}{*}{$20 \%$} \\
\hline & $\begin{array}{l}\text { 2. Secondary gross } \\
\text { enrolment ratio }\end{array}$ & 100 & 33 & \\
\hline & $\begin{array}{l}\text { 3. Tertiary gross } \\
\text { enrolment ratio }\end{array}$ & 100 & 33 & \\
\hline
\end{tabular}

Source: Modified from United Nations International Telecommunication Union (2009)

Note: *This corresponds to a log value of 6.33 , which was used in the normalization step.

The study conducted by Santos \& Tenreyro (2006) stated that OLS estimation can cause bias because in trade cooperation between countries can have zero volume (zero trade volume). If you use a fixed effect, the bias will also occur, because when the data has zero value, the data will be released (zero trade is dropped). In his study, Santos \& Tenreyro (2006) proposed using Poisson Pseudo
Maximum Likelihood (PPML). In our model, we transform real GDP of exporting and importing countries, distance, population, and exchange rate into normal logarithm form. Meanwhile, the IDI is not transformed into the normal logarithm form. This research is taking the period from 2010 to 2017 and there are 9 ASEAN member countries as Indonesian trading partners in this observation. 
Table 3. Operational Definition of Variable of Regression Model

\begin{tabular}{|c|c|c|c|c|}
\hline Notation & Abbreviation & Variable Definition & Nominal & Data Source \\
\hline$e_{\mathrm{ijt}}$ & $\begin{array}{l}\text { Bilateral Trade } \\
\text { (Export) }\end{array}$ & $\begin{array}{l}\text { Bilateral trade (export) } \\
\text { between country i and } \\
\text { country j, year t }\end{array}$ & US\$ & UN-Comtrade \\
\hline rgdp $_{\text {it }}$ & $\begin{array}{l}\text { Real Gross } \\
\text { Domestic Product } \\
(\text { GDP) }\end{array}$ & $\begin{array}{l}\text { Real GDP in constant } 2010 \\
\text { US\$ country i, year } t .\end{array}$ & US\$ & WDI-WB \\
\hline $\operatorname{rgdp}_{\mathrm{jt}}$ & $\begin{array}{l}\text { Real Gross } \\
\text { Domestic Product } \\
\text { (GDP) }\end{array}$ & $\begin{array}{l}\text { Real GDP in constant } 2010 \\
\text { US\$ country j, year t. }\end{array}$ & US\$ & WDI-WB \\
\hline dist $_{i j}$ & Distance & $\begin{array}{l}\text { Distance between country i } \\
\text { and country j. }\end{array}$ & Miles & Distancefromto.net \\
\hline idi $_{j t}$ & $\begin{array}{l}\text { ICT Development } \\
\text { Index }\end{array}$ & $\begin{array}{l}\text { The progression of country } \\
\text { to become an information } \\
\text { society country j, year } \mathrm{t}\end{array}$ & Index & ITU \\
\hline pop $_{\mathrm{jt}}$ & Population & $\begin{array}{l}\text { Population of country j at } \\
\text { year } t \text {. }\end{array}$ & People & WDI-WB \\
\hline rer $_{i j t}$ & $\begin{array}{l}\text { Real Exchange } \\
\text { Rate }\end{array}$ & Exchange rate of country $\mathrm{j}$. & $\begin{array}{l}1 \text { USD = } \\
\text { currency of } \\
\text { country j }\end{array}$ & WDI-WB \\
\hline
\end{tabular}

The majority of the studies on the gravity model use total bilateral trade flows as a dependent variable. However, the use of total bilateral trade flows could not distinguish between the impact of ICT development on export and import term. Therefore, this study is using only the value of exports (in U.S. dollars) as a proxy of trade performance. The Real GDP variable in this study is the final value of goods and services produced by the destination country for a year. The GDP data used in the form of real GDP data at constant prices in 2010 converted from domestic currency into USD using the official rate for each year. GDP data was obtained from the World Bank in million USD between 2010 and 2017. The distance variable in this study is the distance between Indonesia and its trading partners which is calculated by unit kilometers $(\mathrm{km})$. Distance, in this case, is the distance of the capital of the two countries that are measured by air. The data obtained refers to the site www.distancefromto.net. The ICT Development Index (IDI) is an index published yearly by the United Nations ITU since 2009. The index is based on the international agreement of ICT indicators. This makes it a respected indicator to measure the wellinformed society and vice versa.

The IDI as a proxy of ICT Development, is a standard tool for governments, Non-Governmental Organizations (NGOs), operators, 
practitioners, academicians, and others so they can get benefit from the index. The first benefit is, to measure the digital divide of society that means, a gap between those who have ready access to digital technology, and those who do not. The second is, to compare ICT performance across countries. The ICT Development Index consists of 11 ICT indicators and grouped in three indices such as (1) ICT access; (2) ICT use; and (3) ICT skills. The IDI aims to estimate, [1] The level and gradual advancement of ICT improvements annually within countries and the experience of those countries compare to other countries; [2] Enhancement in ICT development in both developed and developing countries; [3]The digital divide, that means, gaps between countries concerning their levels of ICT development; [4] The potential for ICT development and to what extent countries can use it to improve growth and development in the terms of skills and capabilities. [5] Transformation in countries at various levels of ICT development. Therefore, it depends on a limited dataset that can be established with sensible trust in countries at all stages of development.

In this study, we used a population of importing countries. The population variable in this study is the number of population in each export destination country which is calculated by the unit of thousand people. Data was obtained from The World Bank from 2010 to 2017. An effective real exchange rate measures the value of a currency against a basket of other currencies; it takes into account changes in relative prices and shows what can be bought. We have collected the data from each country. The data source is from the World Bank in percent between 2010 and 2017. The dependent variable in the model is trade flow (bilateral export). Meanwhile, there are five dependent variables are considered as explanatory variables, consist of two variables that show the core of Gravity model theory, such as RGDP (Real Gross Domestic Product) of Indonesian partners in ASEAN and distance. Other explanatory variables are ICT which is the center of this model, accompanied by population and RER (Real Exchange Rate). 


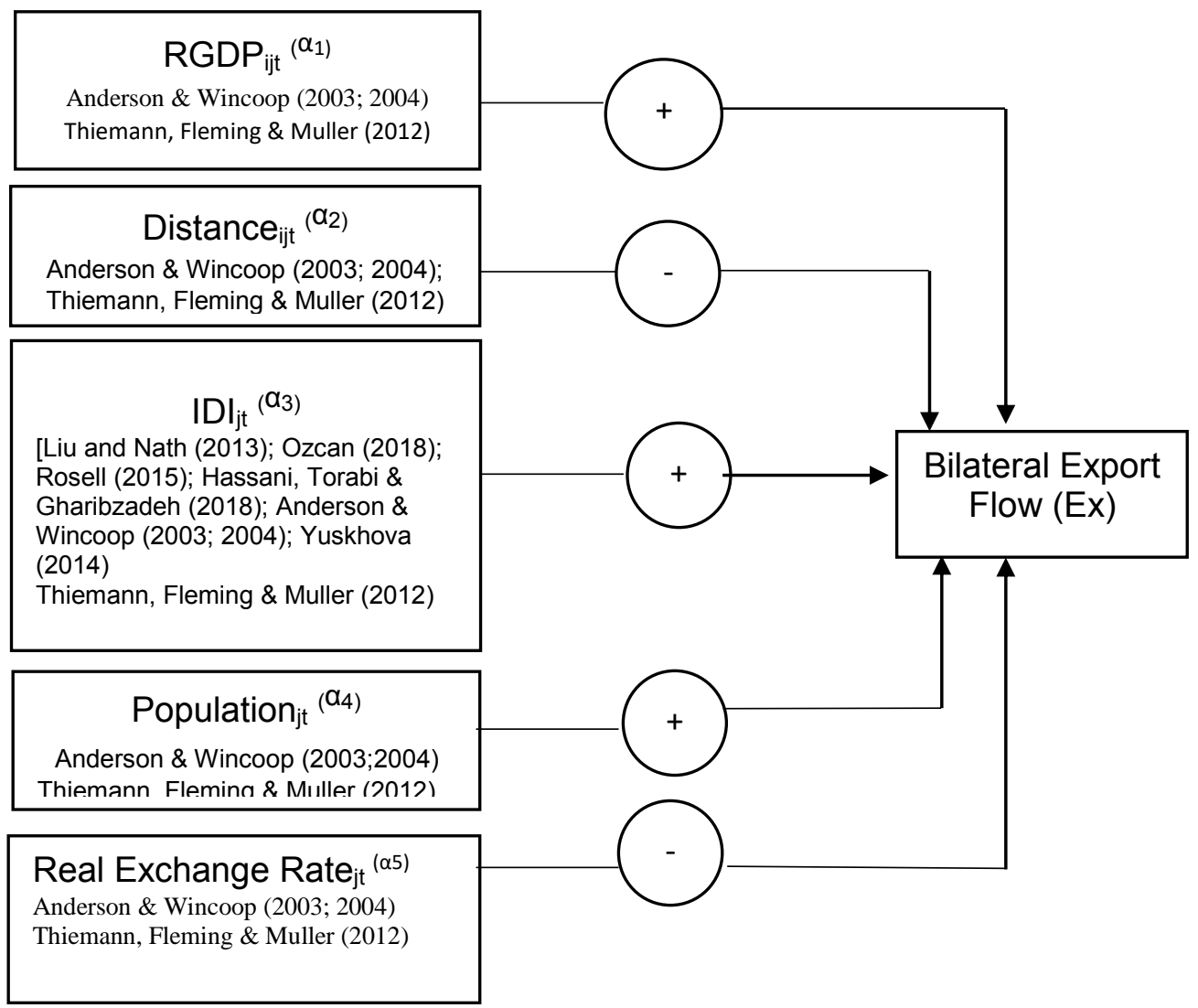

Figure 2: Framework of Analysis Based on Gravity Model

Source: Author Estimation (2018)

\section{Hypothesis}

The hypotheses of this research are captured in the same figure in the framework of analysis as indicated in figure 2. In this framework of analysis, the variable of RGDP expected to have a negative and significant effect on bilateral export, also distance and exchange rate expected to have a negative and significant effect on bilateral export. Meanwhile, IDI and the population expected to have a positive and significant effect on bilateral export.
Introducing Information and Communication Costs into a Gravity Model of Bilateral Trade

The role of information and communication costs is not straightforwardly presented in the model. For example, whether information communication costs are justified to affect the fixed or variable costs of international trade, it depends on the communication's role in the transaction. If communication is substantially relevant in trade facilitating for trading partners, then information 
and communication costs could be seen as affecting the fixed or variable costs of trading. This evidence is invented by Freund \& Weinhold (2004), they found that internet has a positive and significant impact on bilateral trade also Harris (1995), he argues that ICT for international trade is important to support communication networks between supplier and customers. Communication between the sellers and buyers, however, also important. For example, to engage the attention of the manufacturing process of a product with special characteristics and time efficiency. In other words, the consumer and producer need to cooperate with each other in order to produce a customized commodity that that suitable for producers as well as consumers' desire. The extent of such interaction mostly depends on the character of the product and affect both the fixed and variable costs of trade. Apparently, that communication costs affect trade mainly by influencing variable trade costs between two countries.

The theory of information and communication costs allows us to employ a Gravity model of bilateral trade, which is broadly observed as a powerful model to capture international trade both theoretically and empirically in the economic concept. Conversely, the literature on searching costs and buyer or seller engagement does not offer convenient models that easily provide themselves with the empirical application. Therefore, this research employs the following regression equation for bilateral trade between country $\mathrm{i}$ and $\mathrm{j}$.

\section{Regression Model Specification}

In this paper, the effect of the ICT Development Index on Indonesia's bilateral trade toward ASEAN countries is estimated based on the regression model. The equation of this study is formally provided by:

$\ln \operatorname{ex}_{i j t}=\alpha_{0}+\alpha_{1} \ln \operatorname{rgdp}_{i j t}+\alpha_{2} \ln \operatorname{dist}_{i j t}$ $+\alpha_{3} \mathrm{idi}_{j t}+\alpha_{4} \ln$ pop $_{j t}+\alpha_{5} \ln \operatorname{rer}_{j t}+u_{i j t}$ Where:

exijt : trade export flows from country i to country $\mathrm{j}$ at year $\mathrm{t}$

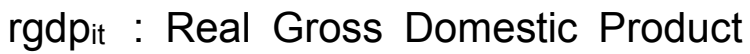
(RGDP) of Indonesia

rgdp $_{\mathrm{jt}}$ : Real Gross Domestic Product (RGDP) of trading partners in ASEAN

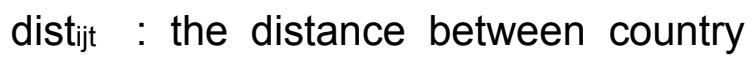
reporter and trading partners

idijt : ICT Development Index (IDI)

popjt $_{j}$ : Population of reporter and trading partners 
rer $r_{j t}$ : Real Effective Exchange Rate (RER) of trading partners

$\mathrm{U}_{\mathrm{ijt}} \quad$ : random error term

$\alpha_{0} \quad$ : constant

\section{RESULTS AND DISCUSSION}

Based on the IDI data, the top three countries that have high IDI among ASEAN countries such as Singapore, Brunei Darussalam, and Malaysia. From the top three, Singapore has the highest ICT Development Index among all Indonesian trading partners. As can be seen in figure 3 , this also becomes a piece of evidence that, the high level of ICT index of Indonesian trading partners in ASEAN countries especially Singapore and Malaysia has supported the bilateral trade flow between two countries. Based on the UN COMTRADE data from 2010 to 2017 , the export value between Indonesia and Singapore as well as Indonesia and Malaysia, are more than other trading partners. This evidence becomes powerful to support the effect of ICT on bilateral trade flow.

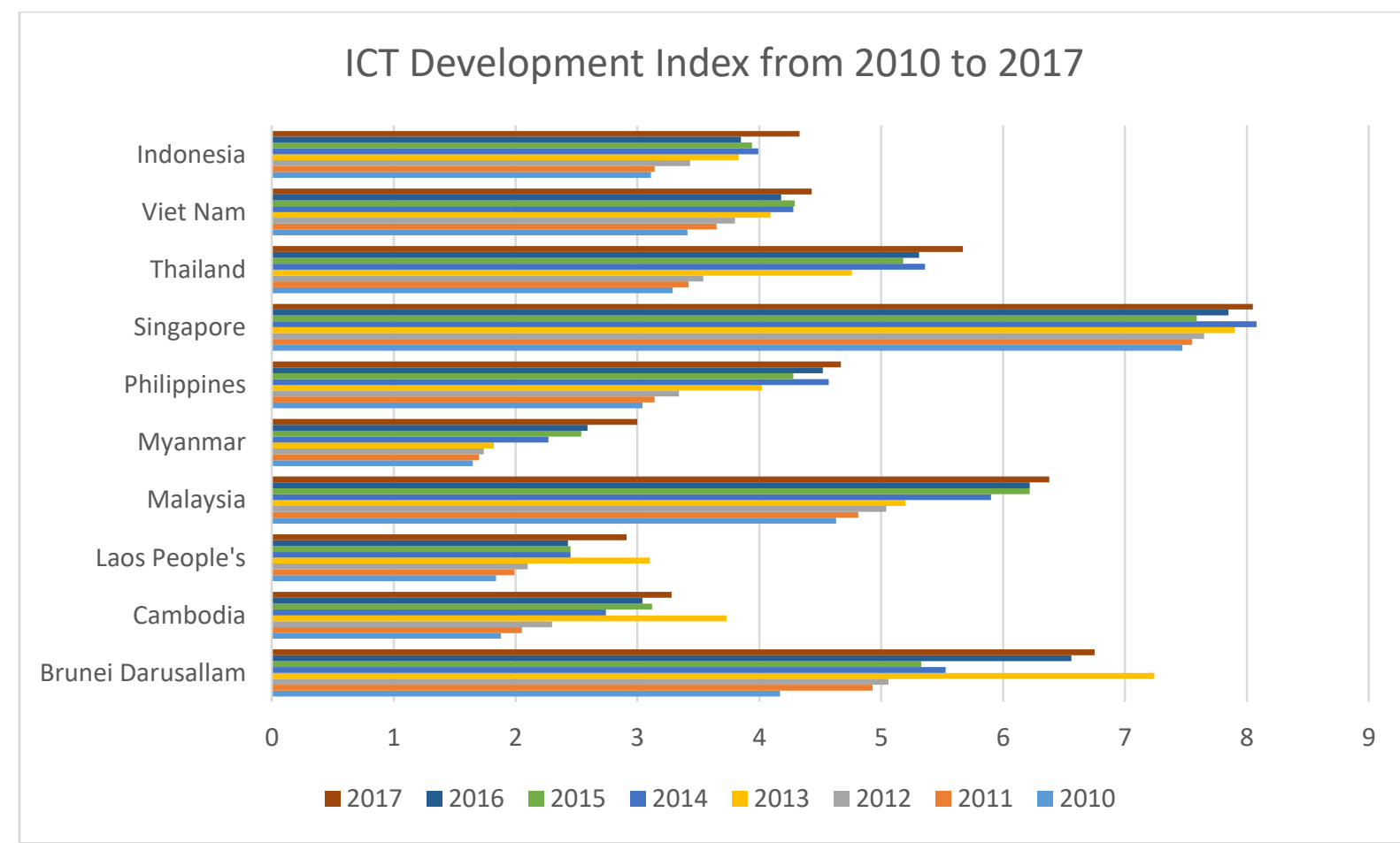

Figure 3. ICT Development Index among 10 ASEAN Countries

Source: ITU Datasets, Global ICT Development Index (2017) 


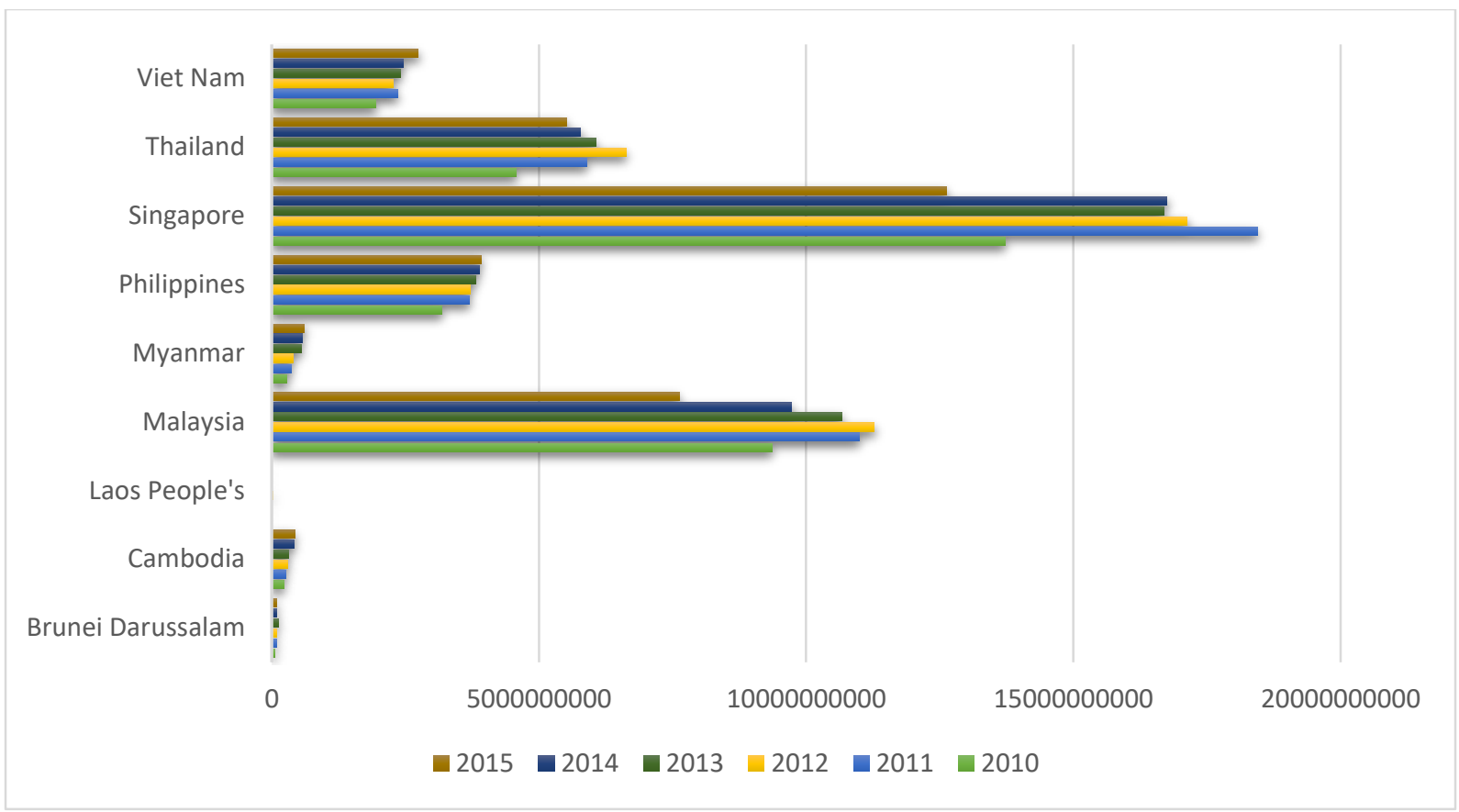

Figure 4. Export from Indonesia to 9 ASEAN Countries from 2010 to 2017

Source: UN Comtrade (2018)

The reason of this evidence is as follow, the first is, the use of ICT may reduce the cost (fixed entry cost) of a market and then might encourage exports. As Freund and Weinhold (2004) argue, these fixed costs include the costs of finding out information about the market (searching cost), advertising, and maintaining a distribution network. The second is, international transactions often require advance planning that involves the opportunity cost of uncertainties. Some of these uncertainties are related to the lag in obtaining and transferring important information. The use of ICT decrease such delays and makes planning more accurate and cost-saving. Consequently, the value of trade between countries is expected to rise.

Several studies have examined the effects of ICT on trade. For example, Freund \& Weinhold (2002) examine how the Internet impacts international trade, especially in services commodity. Researchers include United States (U.S.) both exports and imports of fourteen service commodities and observe thirty-one countries from 1995 until 1999. They found that Internet development in the countries which are observed has a significant and positive effect on bilateral trade with the U.S. Thus, researchers extend their analysis 
further to involve trading in merchandise (instead of service commodities), then to include fifty-six countries in a subsequent study (Freund \& Weinhold, 2004). Moreover, Freund \& Weinhold (2002) also include a theoretical model to explain how the internet is potentially impacting trade. Fink et al. (2005) reveal a significant influence of communication costs on bilateral trade for 107 countries in 1999. Meanwhile, by observing ninety-eight countries, Clarke \& Wallsten (2006) further argue that by increasing access to the Internet this may improve export performance in developing countries as well as the country's exports toward developed countries. Vemuri \& Siddiqi (2009) employ panel data for sixty-four countries between 1985 and 2005 . Thus, they conclude that ICT infrastructure and the availability of the internet for profitable transactions have a positive and significant effect on international trade volume. Demirkan et al (2009) using data of 175 countries, also find the evidence of the enhancement bilateral trade is affected by ICT use. Choi (2010) finds more evidence, that internet usage increases services trade for 151 countries for the period 1990 to 2006. Lastly, Mattes et al. (2012) are using data from the European Union (EU) countries. They attempt to investigate the effects of availability and use of ICT on trade. Even though they find an insignificant effect of ICT on E.U. trade, their results recommend that trade is still developed if both trading partners are advanced users of ICT.

\section{Gravity Model Equation for Bilateral Trade}

The correlation between ICT Development and bilateral export between Indonesia and its ASEAN partner must be proven by econometrics estimation to make the evidence more powerful. Table 3 showed estimation results on how the ICT Development Index and other control variables affect bilateral trade between Indonesia and ASEAN. 
Table 3. Regression Results, Dependent Variable: Total Export in USD

\begin{tabular}{|c|c|c|c|c|}
\hline Dependent: In export & Pooled OLS & Fixed Effect & $\begin{array}{c}\text { Random } \\
\text { Effect }\end{array}$ & PPML \\
\hline Independent Variables & & & & \\
\hline In rgdp (Indonesia) & $\begin{array}{c}1.954^{*} \\
(0.450)\end{array}$ & $\begin{array}{c}1.904^{*} \\
(0.455)\end{array}$ & $\begin{array}{c}1.954^{*} \\
(0.450)\end{array}$ & $\begin{array}{l}2.296^{\prime} \\
(0.446\end{array}$ \\
\hline In rgdp (partners) & $\begin{array}{l}1.218^{*} \\
(0.095)\end{array}$ & $\begin{array}{c}1.208^{*} \\
(0.123)\end{array}$ & $\begin{array}{l}1.218^{*} \\
(0.095)\end{array}$ & $\begin{array}{r}1.1^{\prime} \\
(0.064)\end{array}$ \\
\hline In dist & $\begin{array}{c}-0.262^{*} \\
(0.128)\end{array}$ & $\begin{array}{l}-0.248^{*} \\
(0.155)\end{array}$ & $\begin{array}{c}-0.262^{*} \\
(0.128)\end{array}$ & $\begin{array}{r}-0.271^{\star *} \\
(0.125)\end{array}$ \\
\hline idi (partners) & $\begin{array}{c}0.354^{*} \\
(0.085)\end{array}$ & $\begin{array}{c}0.426^{*} \\
(0.110)\end{array}$ & $\begin{array}{c}0.354^{*} \\
(0.085)\end{array}$ & $\begin{array}{r}0.294 \\
(0.050)\end{array}$ \\
\hline In rer (partners) & $\begin{array}{l}-0.056^{*} \\
(0.014)\end{array}$ & $\begin{array}{l}-0.086^{*} \\
(0.043)\end{array}$ & $\begin{array}{c}-0.056^{*} \\
(0.014)\end{array}$ & $\begin{array}{l}-0.052 \\
(0.013)\end{array}$ \\
\hline In pop (partners) & $\begin{array}{c}0.144^{*} \\
(0.080)\end{array}$ & $\begin{array}{c}0.122^{*} \\
(0.120)\end{array}$ & $\begin{array}{c}0.144^{*} \\
(0.080)\end{array}$ & $\begin{array}{r}0.132^{\prime} \\
(0.124)\end{array}$ \\
\hline R-squared & 0.908 & 0.923 & 0.908 & \\
\hline Wald Chi ${ }^{2}$ & & & 73.16 & \\
\hline
\end{tabular}

Source: Author Estimation (2018)

Note: ${ }^{\star * *} p<0.01,{ }^{* *} p<0.05,{ }^{*} p<0.1$; standard errors are in parentheses

In line with previous trade studies, our regression model seems very powerful and has a good fit in defining export flows based on R-squared and $\mathrm{F}$ test. From our estimation result, this research reveals that RGDP of exporting countries has a positive and significant effect on Indonesia's export to ASEAN countries. Moreover, the increase in RGDP of importing countries increases Indonesia's export to ASEAN. Our finding also is supported by Javorcik (2001) that greater RGDP can be translated into greater economic activities in the importing country. If economic activities in exporting and importing countries become greater, they prefer to export more goods and services than imports. As shown by our findings one percentage point increase of real GDP (exporting country) will increase about $1.954 \%$ on Indonesia's export to ASEAN partners. Moreover, one percentage point increase of real GDP (importing countries) will increase $1.218 \%$ on Indonesia's export to ASEAN partners. A positive sign in RGDP reporter and RGDP partners is in line with the Gravity model theory.

Meanwhile, according to the result, one percentage point increase in distance between countries will reduce the export flows of Indonesia with ASEAN partners as much as $0.262 \%$. Similar to the previous study by Disdier \& Head (2008), distance affects the 
transportation cost of the goods. The further the distance, the more expensive the cost, hence it will reduce the export flows of Indonesia. Aziz \& Bakar (2016) analyzed the general impact of the ECOWAS regional integration agreement on bilateral trade using the gravity model. The results show that distance has a negative and significant relationship on the trading volume between 15 ECOWAS countries. This result is in line with the gravity model. Besides, any increase in the total population of importing countries will affect $0.144 \%$ enhancement of the total export of Indonesia. In accordance with Cincotta \& Engelman (1997), this study shows that an increased population will attract more export flows due to the high demand for goods. Our regression result also suggests that the exchange rate of importing countries has a negative impact on Indonesia's export, which means that a 1 percent increase in the exchange rate means depreciation in the exchange rate of importing countries. Therefore, it will affect the lower export of Indonesia (Bostan, Toderascu \& Firtescu, 2018); Putri (2017).

Result also finds that ICT Development Index in the importing countries have significant and positive effect on export. This finding is consistent with the World Bank (2000) which implies that improved technology, such as communication, will affect the lower levels of trade barriers. Wolf (2003) also noted that through the internet, the global cost of communication is now reduced to zero. Lower global communication cost has facilitated an increase in global trade through cost reduction. There are previous studies about Information and $\mathrm{C}=$ communication Technology (ICT) and how it influences positively on trade using panel data, such as Liu \& Nath (2016); Ozcan \& Nath (2016); Ozcan (2018). Liu \& Nath (2016) in their research using panel data for 49 countries from 2000 to 2013, this paper empirically examines the impacts of ICT on exports and imports of ten service categories. Unlike most previous studies, seven different ICT variables are used to construct a comprehensive ICT development index (IDI) that captures the access, use, and skill aspects of the technology. Moreover, Ozcan \& Nath (2016) study the impacts of information and ICT on international trade between Turkey and its trading partners. Based on an extended panel 
gravity model, the effects of four ICT indices on Turkish bilateral exports and imports are examined with static and dynamic panel data models for the period 2000-2014. The sample includes 35 countries that import Turkish goods and 34 countries that export goods to Turkey. The results indicate that ICT has positive and significant impacts on both Turkish import and export volumes. Additionally, ICT has a larger effect on imports than on exports. Among ICT indices, ICT access has the largest effect on exports while ICT skills have the strongest impact on imports. In contrast, ICT use has the least impact on both Turkish exports and imports. In addition, Ozcan (2018) analyzes the impacts of information and Communication technologies (ICTs) on international trade between Turkey and its trading partners. Using an extended gravity model framework of panel data, this study examines the effects of four ICT indices on Turkish bilateral exports and imports with static and dynamic panel data models for the period between 2000 and 2014. The sample includes 35 countries that import Turkish goods and 34 countries that export goods to Turkey. The results indicate that ICT has a positive and significant impact on both Turkish import and export volumes. Additionally, ICT has a larger effect on imports than on exports. According to these results, some policies can be recommended. For instance, Turkey might develop a strategic policy toward trading partnerships with countries that have achieved high levels of ICT development, in order to increase its trade.

Another previous study such as Thiemann, Fleming, \& Mueller (2012) test the hypothesis of an ICT effect on trade in bananas, oranges, tomatoes, and vegetables and fruit in general. They employ a gravity model of international trade between major exporting and importing countries for the period 1995 to 2009. The model explains the value of trade in terms of export and import countries' levels of internet and mobile phone penetration, and of a broad range of factors that might also affect bilateral trade. They test whether a fixed-effects model or random-effects model best suits the data, results suggest a fixed effects model is appropriate. Model results suggest that cell phone penetration significantly stimulates trade in vegetables and fruit and oranges by 
exporting countries, but its impact is less than that of fixed telephone usage which has an unexpected negative influence on banana imports. Internet usage has only a positive effect on trade in imports of tomatoes. Internet usage in exporting countries for fruit and vegetables are negatively associated.

Moreover, Liu \& Nath (2013) estimate the effects ICT on international trade in emerging markets. Using panel data for 40 emerging market economies (EMEs) for a period from 1995 to 2010, they estimate fixed-effects models of exports and imports with ICT as the main explanatory variable of interest. Their ICT variables include the growth of telecommunication investment, international Internet bandwidth, Internet subscriptions per 100 people, and the number of Internet hosts per 100 people. The first two variables represent ICT infrastructure while the last two represent the use of ICT. They use the share of total exports and total imports in GDP as the dependent variables. Additionally, They consider the GDP share of exports and imports for goods and services separately. The main control variables such as per capita GDP growth, population growth, and country and year fixed effects.
Furthermore, Yushkova (2014) employs the business internet usage index to estimate the effect of the Internet on total exports of goods in 2011 for 40 countries (OECD countries plus Brazil, China, India, Indonesia, Russia, and South Africa). She finds that Internet usage by business communities in both exporting and importing countries has a positive link with the export flows between these countries. The next section discusses data and variables' definitions, methodology and model specification. To the best of our knowledge, based on literature, there is no research that studies on ICT Development Index (IDI) and focuses on how ICT impacts bilateral trade in ASEAN countries, therefore, the researcher intends to fill this gap.

In addition, Rosell (2015) analyzed the effects of internet usage on bilateral trade volumes. Increasingly companies are conducting business online. If the effect of increased internet usage on trade is positive then it would be yet another reason for policymakers to invest in the development and expansion of IT infrastructure. Three main models are specified using the fixed effects estimator, including the least-squares estimator and a Poisson 
maximum likelihood estimator. This paper uses an extensive panel data set of 180 countries and the most recent internet usage data available between 2000 and 2014 to examine the effects of internet usage on bilateral trade. By using a gravity model, the result is indicating a significant positive relationship between internet usage and bilateral trade performance. The effect is larger when more weight is given to countries with smaller internet usage rates. The spatial relationship of this effect is also examined via a HausmanTaylor estimation and a random-effects model. The results from these models indicate that there is a proximity effect, the larger the distance between trading countries, the smaller the effect of internet usage on trade. Besides, Hassani, Torabi and Gharibzadeh (2015) using the gravity model investigate the influence of some indices in terms of ICT on trade flows. In the theoretical concept, researchers gain ICT's indices (ICTi and ICTj) to Anderson and Wincoop (2003; 2004) gravity model. In an empirical approach, in addition to GDP, population, geographical distanc,e and some dummy variables, they expand ICT indices into three separate indices in gravity equations: telecom services investment, percentage of individuals using the internet, and international internet bandwidth. They run the model in two methods for each of these indices: generalized least squares and fixed effects. The dependent variables of our study are export values and import values. Results show that telecom services investment is more robust than two other indices and has expected signs i.e. telecom services investment in two methods has a positive effect on export and import values and coefficients are significant. However, for the percentage of internet users, some of our estimate results do not show expected signs or coefficients are not significant. The third index, for example, international internet bandwidth, has no significant or remarkable coefficients.

Xing (2017) examines the impact of Internet and e-commerce adoption on bilateral trade flows using a panel of 21 developing- and least-developed countries and 30 OECD countries. Given the commitment of the East African Community (EAC) to become the frontrunner in the export-led economy across the African continent, special attention is dedicated to 
analyzing the role of ICT and ecommerce on EAC's export performance. The empirical results indicate that better access to modern ICT and the adoption of e-commerce applications stimulate bilateral trade flows at various levels. The study notes that the efficient use of ICT equipped with highspeed internet and secured servers are a crucial milestone for unlocking the e-trade potentials for developing- and least-developed counties.

Finally, Yadav (2014); Meijers (2014); Faqin (2015); Visser (2018) study on the effect of the internet on trade. Faqin (2015) \& Meijers (2014) studied the effect of the internet on international trade. They both find a positive impact of internet on trade. Meanwhile, Yadav (2014) \& Visser studied the impact of internet penetration on the trade margins. Yadav (2014) argues that Internet use is expected to reduce fixed informationrelated costs of entering international markets. This study looks at the impact of internet use by developing country firms from Asia and Sub-Saharan Africa on their export and input import behavior. Using the enterprise survey dataset from the World Bank, the study finds that, e-mail and own website use have a positive impact on the extensive margin of enterprise export and input import behavior but not on the intensive margin. Meanwhile, Visser (2018) investigates the effect of internet penetration in the form of broadband subscriptions on the extensive and intensive margins of differentiated exports and assesses whether the internet bridges the linguistic gap in trade. Results tentatively indicate that there is a positive association between an increase in internet penetration and the extensive and intensive margins of differentiated exports. Splitting the sample into development levels, internet penetration may facilitate the extensive margin of exports between low and highincome countries, but not within these groups. Lastly, an increase in internet penetration may decrease the effect of linguistic distance on the extensive and intensive margins of differentiated exports.

\section{CONCLUSION AND POLICY RECOMMENDATION}

As can be seen in the regression results in table 3 , five control variables accompanied ICT Development index such as RGDP of Indonesia, RGDP of partners, distance, the population of 
partners and RER of partners are significant in the degree of $1 \%$ and $5 \%$ toward Indonesian export. In addition, the result shows that distance has a negative and significant effect on Indonesia's export. The regression model specification shows that distance as a representation of transportation has a significant impact on Indonesian export to ASEAN countries. The shorter distance from Indonesia to its partner, the higher the export. This result is in line with the Gravity model theory. Besides, the population has a positive effect on Indonesian export, the trade policy of Indonesian government should direct to the countries that have a large size of population. Moreover, ICT Development has a positive and significant impact on Indonesia's export, therefore, Indonesia shall develop strategic trading partnerships with countries that have achieved high levels of ICT development and ICT endowments, such as Singapore and Malaysia in order to increase Indonesia's ICT based products to ASEAN countries.

\section{ACKNOWLEDGEMENT}

Firstly, it is my utmost pleasure to dedicate this work to my institution, Universitas Muhammadiyah Yogyakarta who granted me the support and encouragement. Also my family, of their unwavering belief in my ability to accomplish this goal. I wish to express my appreciation and thank you to Buletin IImiah Litbang Perdagangan (BILP)'s editor and reviewers who provided their time, effort, and support for this publication. To Editor, Dr. Zamroni Salim. and also Sister Maulida Lestari, thank you for sticking with me. Finally, a special thanks to the Ministry of Trade of the Republic Indonesia for their continuous support, their appreciation for my work, and for that, I will be forever grateful.

\section{REFERENCES}

Anderson, J.E. \& van Wincoop, E. (2003). Gravity with Gravitas: A Solution to the Border Puzzle. The American Economic Review, 93(1), 170-192.

Anderson, J.E. \& van Wincoop, E. (2004). Trade Costs. Journal of Economic Literature, 42(3), 691-751.

ASEAN Framework Agreement for the Integration of Priority Sector. (2004). ASEAN Document (Online). https://asean.org/?static_post=aseanframework-agreement-for-theintegration-of-priority-sectorsvientiane-29th-november-2004. Retrieved on 6 July 2019.

ASEAN Economic Community Blueprint. (2008). ASEAN Document (Online). https://asean.org/wpcontent/uploads/archive/5187-10.pdf. Retrieved on 6 July 2019.

Baltagi., H. B. (2008). Econometric Analysis of Panel Data. Third Edition. USA: Wiley. 
Bostan I., Toderascu C., Firtescu B. N. (2018). Exchange Rate Effect on International Comercial Trade Competitiveness. Journal of Risk and Financial Management, 11(2), 19.

Choi, C. (2010). The Effect of the Internet on Service Trade. Economics Letters, 109(2), 102-104.

Cincotta, R.P. \& Engelman,.R. (1997). Economic and Rapid Change: The Influence of Population Growth. Occasional Paper.

Clarke, G.R.G. \& Wallsten, S.J. (2006). Has the Internet Increased Trade? Developed and Developing Country Evidence. Economic Inquiry 44(3), 465-484.

Demirkan, H., Goul, M., Kauffman, R.J., \& Weber, D. M. (2009). Does Distance Matter? The InflueOnce of ICT on Bilateral Trade Flows. In Proceedings of the 2nd Annual SIG GlobDev Workshop. Phoenix: Association for Information Systems (available at www.globdev.org/?q =node/71/).

Disdier, A.C. \& Head, K. (2008). The Puzzling Persistence of the Distance Effect on Bilateral Trade. Review of Economics and Statistics, 90(1), 3748.

Faqin L. (2015). Estimating the Effect of the Internet on International Trade. The Journal of International Trade \& Economic Development, Taylor \& Francis Journals, 24(3), 409-428.

Fink, C., Mattoo, A. \& Neagu, I.C. (2005). Assessing the Impact of Communication Costs on International Trade. Journal of International Economics 67(2), 428-445.

Freund, C. \& Weinhold, D. (2002). The Internet and International Trade in Services. American Economic Review, 92(2), 236-240.

Freund, C. \& Weinhold, D. (2004). The Effect of the Internet on International Trade. Journal of International Economics, 62(1), 171-189.
Harris, R.G. (1995). Trade and Communication Costs. Canadian Journal of Economics, 28, S46-S75. (Special Issue)

Hassani, F.H., Torabi, T., Gharibzadeh, S. (2015). Effect of Information and Communication Technology on Trade Flows Using Gravity Model. Asia Pasific Institute of Advanced Research, 30-39.

International Telecommunication Union (ITU). (2010). http://www.itu.int/en/ ITU-

D/Statistics/Pages/publications/mis20 17/methodology.aspx.

International Telecommunication Union (ITU). (2011). http://www.itu.int/en/ ITU-

D/Statistics/Pages/publications/mis20 17/methodology.aspx.

International Telecommunication Union (ITU) Datasets, Global ICT Development Index. (2017). http://www.itu.int/net4/ITUD/idi/2017/index.html, retrieved on 17 August 2018.

Javorcik, B. S. (2001). Integration into Global Production and Distribution Networks Through FDI: The Case of Poland. Communist Economics and Economic Transformation, 13(4).

Linder, S. B. (1961). An Essay on Trade and Transformation. John Wiley and Sons, New York.

Linnemann, H. (1966). An Econometric Study of International Trade Flows. the University of California.

Liu, L. \& Nath, H. K. (2013). Information and Communications Technology and Trade in Emerging Market Economies. Journal Emerging Markets Finance and Trade, Taylor \& Francis Journals, 49(6), 67-68.

Liu, L. \& Nath, H. (2016). Information and Communications Technology (ICT) and Services Trade, Sam Houston State University, Department of Economics and International Business Working Paper No. 16-01 January. 
Masterplan on ASEAN Connectivity (2014). ASEAN Document (Online). https://www.asean.org/storage/image s/ASEAN_RTK_2014/4_Master_Plan _on_ASEAN_Connectivity.pdf

Mattes, A., Meinen, P., \& Pavel, F. (2012). Goods Follow Bytes: The Impact of ICT on EU Trade. DIW Berlin Discussion Paper no. 1182, German Institute for Economic Research, Berlin.

Meijers, H. (2014). Does Internet Generate Economic Growth, International Trade, or Both? International Economics and Economic Policy, 11(1), 137-163.

Ozcan, B. \& Nath, H. (2016). Information and Communication Technology (ICT) and International Trade: Evidence from Turkey. Working Papers 1609, Sam Houston State University, Department of Economics and International Business.

Ozcan, B. (2018). Information and Communication Technology (ICT) and International Trade: Evidence from Turkey. Economics Department Firat University Elazig Turkey, 8(1), 93-113.

Pangestu, M. E. (2010). Competitiveness towards ASEAN Economic Community. Journal of Indonesian Economic and Business 24(1), 22-32.

Putri, N. H. (2017). Analisis Pengaruh PDB dan Kurs Dollar Amerika Terhadap Neraca Perdagangan Melalui Foreign Direct Investment di Indonesia Tahun 1996-2015. E-Jurnal EP Universitas Udayana, 6(9).

Rosell, F. S. (2015). The Internet and Trade: An assessment of the effects of internet usage on trade volumes. Lund University Libraries.

Sally, R. \& Sen, R. (2005), Trade Policy in Southeast Asia in the Wider Asian Perspective.

Santos, S. J. \& Tenreyro, S. (2006). The Log of Gravity. Review of Economics \& Statistics, 88(4), 618-641
Sciadas, G. (2003). Monitoring the Digital Divide and Beyond. Accessed 2003 Orbicom, Montreal. http://www.orbicom.uqam.ca/projects/ ddi2002/2003_dd_pdf_en.pdf. Retrieved on $\overline{6}$ July $20 \overline{19}$.

The World Bank. (2000). World Development Report 2000. Oxford University Press: Washington, D.C.

Thiemann, F., Fleming, E., \& Mueller, R.A.E. (2012). Impact of Information and Communication Technology (ICT) on International Trade in Fruit and Vegetables: A Gravity Model Approach. International Association of Agricultural Economists Conference, August 18-24, 2012, Foz do Iguaçu, Brazil, http://purl.umn.edu/123840.

Vemuri, V.K., \& Siddiqi, S. (2009). Impact of Commercialization of the Internet on International Trade: A Panel Study Using the Extended Gravity Model. International Trade Journal 23(4),458484.

Visser, R. (2018). The Effect of the Internet on the Margins of Trade. Information and Economics Policy.

Wolf, M. (2003). Is Globalization in Danger? The World Economy, 26(5), 313-412

Xing (2017). The Impacts of Information and Comunications Technology (ICT) and E-cormmerce on Bilateral Trade Flows. International Economics and Economic Policy, April.

Yadav, N. (2014). The Role of Internet Use on International Trade: Evidence from Asian and Sub-Saharan African Enterprises. Global Economy Journal. 14(2), 189-214.

Yushkova, E. (2014). Impact of ICT on Trade in Different Technology Groups: Analysis and Implications, International Economics and Economic Policy, 11(1), 165-177. 
